\title{
The Bushlike Radiation of Muroid Rodents Is Exemplified by the Molecular Phylogeny of the LCAT Nuclear Gene
}

\author{
Johan Michaux and François Catzeflis \\ Laboratoire de Paléontologie, Institut des Sciences de l'Evolution, UMR 5554 CNRS, \\ Université de Montpellier 2, 34095 Montpellier, France
}

Received January 11, 2000; revised July 26, 2000

\begin{abstract}
Phylogenetic relationships among 40 extant species of rodents, with an emphasis on the taxonomic sampling of Muridae and Dipodidae, were studied using sequences of the nuclear protein-coding gene LCAT (lecithin cholesterol acyl transferase). Analysis of 804 bp from the exonic regions of LCAT confirmed many traditional groupings in and around Muridae. A strong support was found for the families Muridae (represented by 29 species) and Dipodidae (5 species). Compared with Sciuridae, Gliridae, and Caviomorpha, the Dipodidae family appeared the closest relative of Muridae, confirming the suprafamilial Myodonta concept. Within the speciose family Muridae, the first branching leads to the fossorial Spalacinae and semifossorial Rhyzomyinae. The remaining components of Muridae appear as a polytomy from which are issued Sigmodontinae, Calomyscinae, Arvicolinae, Cricetinae, Mystromyinae, Nesomyinae, and some Dendromurinae (Steatomys and Dendromus). This phylogeny is interpreted as the result of a bushlike radiation at the end of the early Miocene, leading to emergence of most living subfamilies. The separation between three additional taxa, Murinae, Gerbillinae, and "Acomyinae" (which comprises the genera Acomys, Deomys, Uranomys, and Lophuromys), has occurred more recently from a common ancestor issued from the main basal radiation. As previously shown by other molecular studies, the vlei rats, Otomyinae, are nested within Old World Murinae. In the same way, the zokors, Myospalacinae, appear strongly nested within the hamsters, Cricetinae. Finally, we propose a sister group relationship between Malagasy Nesomyinae and south African Mystromyinae. $\bigcirc 2000$ Academic Press

Key Words: phylogeny; Muridae; Myodonta; radiation; LCAT.
\end{abstract}

\section{INTRODUCTION}

The rodents of the family Muridae (as defined by Musser and Carleton, 1993, and corresponding to the superfamily Muroidea of McKenna and Bell, 1997) are the most diverse group of mammals, encompassing at least 1326 species spanning more than 281 genera (Musser and Carleton, 1993). Thus, this single rodent taxon represents about 29 and $25 \%$ of all mammalian species and genera, respectively. The evolutionary systematics of this speciose family has been very difficult and despite many attempts (i.e., Miller and Gidley, 1918; Simpson, 1945; Hooper and Musser, 1964; Chaline et al., 1977; Carleton, 1980), many uncertainties, confusions, and conflicting views have persisted for these animals. For this reason, in their recent review, Musser and Carleton (1993) decided to keep a prudent state of uncertainty of the hierarchical pattern of muroid suprageneric groups and to divide the family Muridae into 17 subfamilies considered at the same taxonomic level. These "major lineages" within murids are Arvicolinae*, Calomyscinae*, Cricetinae*, Cricetomyinae, Dendromurinae*, Gerbillinae*, Lophiomyinae, Murinae*, Myospalacinae*, Mystromyinae*, Nesomyinae*, Otomyinae*, Petromyscinae, Platacanthomyinae, Rhizomyinae*, Sigmodontinae*, and Spalacinae* (a star denotes taxa investigated in this study). Murid species and genera are not equally distributed among these subfamilies: most of them are included in the Old World rats and mice, Murinae (respectively, 40 and $45 \%$ ), the New World rats and mice, Sigmodontinae (32 and $28 \%$ ), the voles and lemmings, Arvicolinae (11 and 6.5\%), and the gerbils, Gerbillinae (7 and $6 \%$ ). Some of these subfamilies are very depauperate, such as the maned or crested rats, Lophiomyinae (1 species), the white-tailed mice, Mystromyinae (1 species), or the mouse-like hamsters, Calomyscinae (1 genus and 6 species).

Although some Muridae species (i.e., from the genera Mus, Peromyscus, Mesocricetus, Phodopus, Rattus, etc.) have been used often in laboratories for genetic, physiological, or behavioral studies, there remains a strong need to better define the taxonomic boundaries of these subfamilies and especially the relationships among them. Many important questions concerning the evolutionary origins of most of the 17 subfamilies, their rates of evolution, or the sister group relationships between Muridae and other rodent families are not yet adequately answered. 
Paleontological studies have provided important insights into some of these questions. For example, fairly good fossil records in some lineages were the basis for estimating the Mus-Rattus dichotomy $(\approx 12$ million years) (Jaeger et al., 1986; Jacobs et al., 1989, 1990; Jacobs and Down, 1994) and the separation between Spalacinae, Rhizomyinae, and the remaining living Muridae $(\approx 20$ million years) (Flynn, 1990; Hugueney and Mein, 1993). These data are generally used to calibrate the molecular clocks in molecular studies. In another way, clear morphological diagnoses were evidenced to define some subfamilies, such as Gerbillinae (gerbils, jirds, and sand rats), Arvicolinae (voles, lemmings, muskrats), Cricetomyinae (pouched rats and mice), Spalacinae (blind mole rats), Rhizomyinae (bamboo rats and African mole rats), or Cricetinae (hamsters) (Ellerman, 1940, 1941; Ognev, 1963; Carleton, 1980; Carleton and Musser, 1984; Jacobs et al., 1989; Catzeflis et al., 1992). On the contrary, some subfamilies are more resistant to a morphological diagnosis, such as Sigmodontinae (New World rats and mice) or Nesomyinae (Malagasy rats and mice). Finally, some other murid subfamilies might well prove para- or polyphyletic, such as Dendromurinae, whose monophyly was recently challenged by Denys et al. (1995).

Dental and cranial characters commonly used in morphological and paleontological studies are often subject to parallelism, convergence, and reversals events (Carleton and Musser, 1984; Catzeflis et al., 1992). These homoplasic characteristics have restricted their use for inferring the relationships between all subfamilies and have yielded numerous conflicting hypotheses, depending on which characters were emphasized by the various students of muroid systematics (Simpson, 1945; Honacki and Kinman, 1982; Chaline et al., 1977; Hooper and Musser, 1964).

Molecular phylogenetic studies, if based on genes less subject to homoplasy than traditional morphological characters, could produce important complementary information for a better understanding of the evolutionary systematics of Muridae. Currently, too few molecular analyses with the aim of embracing the subfamilial diversity of murids have been performed. Some studies have provided molecular signatures, such as the presence of a repetitive element called Lx for defining Murinae (Pascale et al., 1990; Furano et $a l .$, 1994). Catzeflis et al. (1993), through DNA/DNA hybridization, proposed that cricetines, arvicolines, sigmodontines, and possibly Mystromys were clustered in a clade, separate from the murines, gerbillines, and spalacines. On the basis of 12S rRNA mitochondrial sequences and DNA/DNA hybridization, Dubois et al. (1996) suggested the monophyly of Nesomyinae and a sister group relationship of these with the African Cricetomyinae. Chevret et al. (1993a, 1994), Hänni et al. (1995), and Dubois et al. (1999), on the basis of
DNA/DNA hybridization and molecular sequences (12S rRNA and nuclear ribonucleases, respectively), confirmed the hypothesis of Denys et al. (1992) against the monophyly of Murinae and Dendromurinae and proposed to erect a new "Acomyinae" subfamily. This additional muroid lineage clusters genera which were previously classified as members of Murinae (Acomys, Uranomys, Lophuromys) or Dendromurinae (Deomys). A recent molecular analysis of the mitochondrial cytochrome $b$ gene variation in several subfamilies of murids (Jansa et al., 1999), with a special emphasis on Malagasy Nesomyinae, suggested some suprageneric relationships, but these results are here considered doubtful as an inappropriate outgroup was selected for rooting highly saturated sequences. Finally, Robinson et al. (1997), in a study of LCAT (lecithin cholesterol acyl transferase) nuclear gene sequences, confirmed that Spalacinae and Rhizomyinae were early separated from five other subfamilies that were surveyed. The remaining murids appeared as a polytomy from which were issued Gerbillinae, Murinae, Sigmodontinae, Cricetinae, and Arvicolinae.

However, the former study by Robinson et al. (1997) considered only 7 of the 17 lineages listed by Musser and Carleton (1993). To broaden the picture, we here enlarge the taxonomic sampling of rodents, with a special emphasis on Dipodidae (sampling 4 of 7 subfamilies) and Muridae (13 of 17 subfamilies and four representatives of "Acomyinae"). The nuclear gene LCAT was used, as Robinson et al. (1997) demonstrated that it is a promising marker for this taxonomic level. This gene codes for a key enzyme in the reverse cholesterol pathway and consists of six exons totaling 1320 nucleotides in Homo sapiens (McLean et al., 1986; Warden et al.. 1989).

\section{MATERIAL AND METHODS}

DNA was extracted and purified from ethanol-preserved tissues taken from the Collection of Mammalian Tissues housed at Montpellier (Catzeflis, 1991). Whenever possible, we selected two species for each studied subfamily (see Table 1). This biological sampling was aimed at obtaining an equilibrated representation of each murid lineage and at diminishing a possible longbranch attraction effect.

\section{DNA Sequencing of LCAT Gene}

Two fragments (as in Fig. 1, p. 424, in Robinson et $a l$., 1997) of the nuclear gene LCAT were amplified using the PCR primers previously designed by Robinson et al. (1997). All PCRs used the following protocol: 5 min at $94^{\circ} \mathrm{C}, 33$ cycles $\left(45 \mathrm{~s}\right.$ at $94^{\circ} \mathrm{C}, 30 \mathrm{~s}$ at $52^{\circ} \mathrm{C}$, and $1 \mathrm{~min}$ at $72^{\circ} \mathrm{C}$ ), plus $10 \mathrm{~min}$ at $72^{\circ} \mathrm{C}$ in a Appligen Crocodile 3 thermal cycler. Total reaction volume was $100 \mu \mathrm{l}$. PCR products were purified using the Ultrafree DNA Amicon kit (Millipore) and directlv se- 
quenced. Sequencing on both strands was done using a dye terminator (Perkin-Elmer) sequencing kit and a ABI 373 (Perkin-Elmer) automatic sequencer.

\section{Sequence Alignment and Phylogenetic Reconstructions}

Previously known sequences were extracted from GenBank and aligned with the new sequences using CLUSTAL W (Thompson et al., 1994) and the ED editor (MUST package; Philippe, 1993). The phylogenetic analysis was conducted on 804 nucleotides corresponding to the exonic regions of the two amplified fragments. The aligned sequences were treated by distance (neighbor-joining, NJ; Saitou and Nei, 1987), maximum-parsimony (MP), and maximum-likelihood (ML) analyses using, respectively, MUST (NJboot program; Philippe, 1993; Tamura and Nei (1993) distance estimator), PAUP 4.0b1 (NJ: ME criterion and TBR branch swapping option; MP: heuristic search and TBR branch swapping option (Swofford, 1998)), and PUZZLE version 4.0 (quartet puzzling procedure; Strimmer and Von Haeseler, 1996; Tamura and Nei (1993) model of evolution and mixed ( $1 \mathrm{Inv}+8$ gamma rates) model of among-sites rates heterogeneity). The robustness of inferences was assessed through bootstrap resampling (BP) (1000 repetitions) with the distance and parsimony approaches. In the case of ML, the reliability percentage (RP; Strimmer and Von Haeseler, 1996) estimated the occurrence of the nodes in the quartet puzzling trees after 1000 puzzling steps. Bremer's support index (BSI) (Bremer, 1988) was also calculated on the most-parsimonious tree with enforcement of topological constraints. Likelihoods of alternative topologies were compared with MOLPHY 2.3b3 (Adashi and Hasegawa, 1996) and PUZZLE (Strimmer and Von Haeseler, 1996). According to Kishino and Hasegawa (1989), an alternative hypothesis was rejected when $\delta \operatorname{lnL}>1.96 \mathrm{SE}$, where $\delta \operatorname{lnL}$ is the difference between the log-likelihoods of the best and those of the evaluated trees, and SE is the standard error of this difference.

\section{Relative-Rate Test}

Relative-rate tests were conducted with RRTree, version 1.0 (Robinson et al., 1998), which improves the test of $\mathrm{Wu}$ and $\mathrm{Li}$ (1985) by taking into account the taxonomic representativity and its phylogenetic relationships. Relative-rate tests were performed among rodents at supra- and intrafamilial levels; the ML tree derived from quartet puzzling was chosen as the reference phylogeny. With regard to the different levels of analyses (see below), various outgroups were chosen: primates (Homo and Papio) for tests at the suprafamilial level and Dipodidae for tests between the Muridae subfamilies. Relative-rate tests were performed on the proportions of synonymous (Ks) and nonsynonymous (Ka) substitutions.

\section{RESULTS}

\section{Sequenced Species}

The 21 new rodent sequences of the LCAT gene are indicated in Table 1, where rodent taxa are listed following the taxonomic arrangement of Wilson and Reeder (1993). These sequences have been deposited in the EMBL gene bank under Accession Nos. AJ275513 to AJ275617.

The newly determined sequences have been compared to 17 rodent sequences determined by Robinson et al. (1997), as well as to Mus and Rattus (available in GenBank) (Table 1). We also conducted a few analyses with additional nonrodent taxa as outgroups: two Primates (Homo sapiens, GenBank Accession No. X04981; Papio anubis L08633) and one Lagomorpha (Oryctolagus cuniculus D13668).

\section{Nucleotide Characteristics of LCAT and Analysis of Saturation}

The aligned data matrix includes 43 mammalian species and 804 sites, 456 of which were variable and 317 phylogenetically informative when all events (transitions (TS) and transversions (TV)) are considered; $53 \%$ of variable sites and $65 \%$ of informative sites concern the third position where most synonymous changes take place.

As already shown by Robinson et al. (1997), the mean frequency of nucleotides in the sequences compared shows an overall high GC content in LCAT $(22.0 \% \mathrm{~A}$, $28.2 \% \mathrm{C}, 24.8 \% \mathrm{G}, 25.0 \% \mathrm{~T}, 53 \% \mathrm{GC})$. This value is more pronounced in the third codon position $(61.6 \%$ GC3), where it ranges from 54.8 (Myospalax) to 77.9 (Papio sp.). However, as already shown by Robinson $e t$ al. (1997), this variation in GC content does not seem to affect phylogenetic reconstruction. The average ratio of TS/TV is 1.90, ranging from 0.94 (Spalax ehrenbergi/ Spalax leucodon comparison) to 3.56 (Peromyscus maniculatus/Acomys cahirinus and Mystromys albicaudatus/Acomys cahirinus).

The above differences in base composition and in rates of TS/TV changes indicate that the data matrix is heterogeneous with regard to the different substitution types at each codon position. To better locate homoplasy, we searched for evidence of saturation using the method of Hassanin et al. (1998a, b). This analysis aims at determining the relative importance of multiple substitutions by comparing, in scatterplots, the pairwise numbers of observed versus inferred changes of each of the six substitution types at each codon position. Each of the 18 resulting scatterplots can be characterized by the consistency index (CI) of the mostparsimonious tree and by the slope (S) of the linear regression between observed and inferred changes. Such information provides a rough idea of the level of saturation for each kind of nucleotide substitution (Ta- 
TABLE 1

References of Rodent Tissues Used for the Experiments

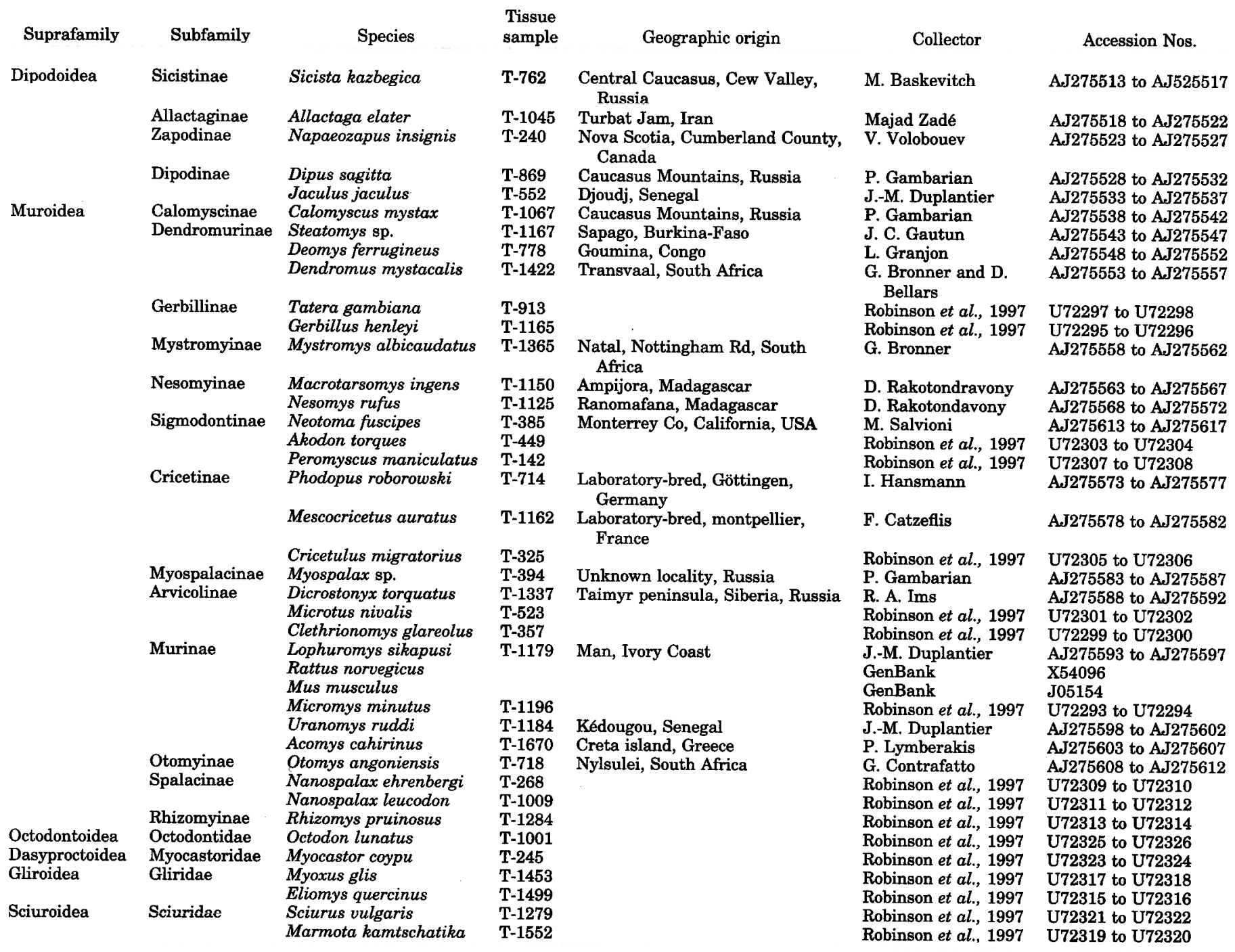

Note. The taxonomic arrangement follows that of Wilson and Reeder (1993).

ble 2). The results show that the C-T and A-G transitions exhibit a lower slope (average, for the three codon positions, of 0.59 for $\mathrm{A}-\mathrm{G}$ and 0.63 for $\mathrm{C}-\mathrm{T}$ ) and consistency index (average of 0.33 for A-G and 0.35 for C-T) with regard to the transversions, whatever the codon position. Considering also the fact that the highest numbers of informative characters are the result of transitional changes (Table 2), this analysis of saturation justifies some down-weighting for A-G and C-T changes.

Consequently, in parallel to a classical unweighted parsimony analysis (MP), we performed a second analysis (MPw) in which we weighted each substitution event according to its slope (taking 1000 times this value for each substitution cell to use the "stepmatrix" option of PAUP).

\section{Phylogenetic Reconstructions}

\section{Analyses with 43 Eutherian Mammals}

A first set of analyses (Table 3, Fig. 1) considered 40 rodents, 2 primates, and 1 lagomorph for all coding sequences (concatenations of exons $2,3,4,5$, and 6 ), that is 804 nucleotides, or 268 amino acids. We excluded three codons corresponding to autapomorphic insertions (one codon for Sciurus vulgaris and two for Microtus nivalis).

The maximum-parsimony reconstruction based on equal weighting of each nucleotide substitution yielded 24 most-parsimonious trees. Each tree is 1541 steps long, with a consistency index (excluding uninformative characters) of 0.38 and a retention index of 0.56 . Bootstrapping and Bremer's support index values are 
TABLE 2

Number of Informative Sites, Consistency Index, and Slope of Saturation for Each of the 18 Substitution Types

$\begin{array}{cccc} & \begin{array}{c}\text { Number of } \\ \text { informative } \\ \text { sites }\end{array} & \begin{array}{c}\text { Consistency } \\ \text { index (CI) }\end{array} & \begin{array}{c}\text { Slope of } \\ \text { saturatio } \\ \text { (S) }\end{array} \\ \text { 1st Codon position } & & & \\ \text { A-C } & 22 & 0.53 & 0.83 \\ \text { A-G } & 47 & 0.32 & 0.57 \\ \text { A-T } & 9 & 0.56 & 0.9 \\ \text { C-G } & 24 & 0.61 & 0.82 \\ \text { C-T } & 41 & 0.38 & 0.66 \\ \text { G-T } & 21 & 0.51 & 0.83 \\ \text { 2nd Codon position } & & & \\ \text { A-C } & 20 & 0.58 & 0.92 \\ \text { A-G } & 42 & 0.36 & 0.69 \\ \text { A-T } & 17 & 0.81 & 0.98 \\ \text { C-G } & 27 & 0.76 & 0.86 \\ \text { C-T } & 49 & 0.39 & 0.71 \\ \text { G-T } & 19 & 0.73 & 0.98 \\ \text { 3rd Codon position } & & & \\ \text { A-C } & 26 & 0.55 & 0.92 \\ \text { A-G } & 41 & 0.32 & 0.52 \\ \text { A-T } & 15 & 0.65 & 0.83 \\ \text { C-G } & 19 & 0.61 & 0.86 \\ \text { C-T } & 64 & 0.29 & 0.54 \\ \text { G-T } & 17 & 0.53 & 0.84\end{array}$

indicated in Table 3 for the ancestral segments labeled A to $\mathrm{H}$ in Fig. 1. There exists a strong support for the families Sciuridae (node D; BP $=99 \%$; BSI $=+12$ ), Gliridae (node E: $100 \%$, +14), Muridae (node H: $99 \%$; +8 ), and Dipodidae (node G: $98 \%$; +6 ), and for the suprafamilial taxon Caviomorpha (node C: $100 \%$; +23). This maximum-parsimony analysis also con-

\section{TABLE 3}

Indices of Robustness for the Nodes of the Phylogenetic Tree Represented in Fig. 1 Using Maximum-Parsimony (MP), Distance, and Maximum-Likelihood (ML) Analyses

$\begin{array}{crrrrr}\text { Nodes } & \text { MP } & \text { MP }_{\mathrm{w}} & \text { BSI } & \text { NJ } & \text { ML } \\ \text { A } & 100 & 100 & +23 & 100 & 90 \\ \text { B } & 96 & 97 & +19 & 94 & 82 \\ \text { C } & 100 & 100 & +23 & 100 & 92 \\ \text { D } & 99 & 99 & +12 & 100 & 85 \\ \text { E } & 100 & 100 & +14 & 100 & 92 \\ \text { F } & 96 & 98 & +8 & 95 & 89 \\ \text { G } & 98 & 99 & +6 & 96 & 92 \\ \text { H } & 99 & 100 & +8 & 97 & 81\end{array}$

Note. Bootstrap percentages computed after standard MP (with equal weighting), MP weighted by slopes of saturation profiles $(\mathrm{MPw})$, and neighbor-joining (NJ) on Tamura and Nei (1993) distances with gamma rates (alpha $=0.38$ ) are reported. Reliability percentages deduced from the quartet puzzling ML methods are also given. Finally, Bremer support indices (BSIs) are indicated.

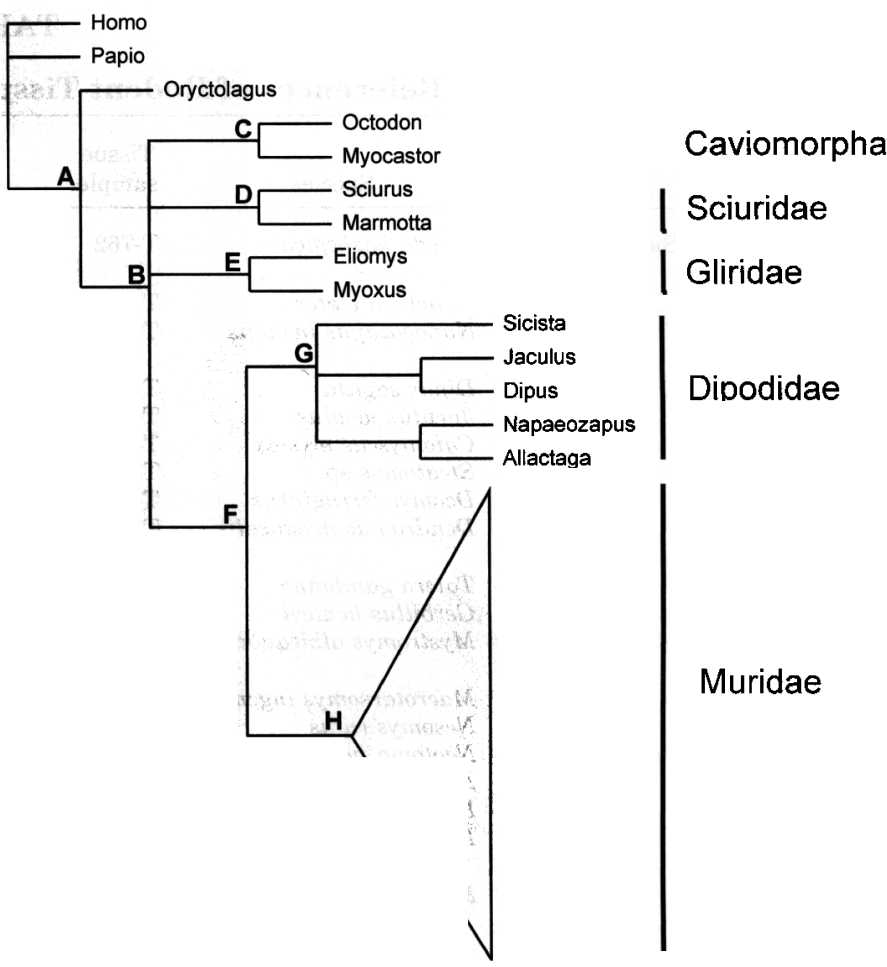

FIG. 1. Synthetic tree summarizing the results derived from three approaches on 43 mammalian DNA sequences of the LCAT gene. The robustness of each node (labeled A to $\mathrm{H}$ ) is described in Table 3 for maximum-parsimony (bootstrap percentage and Bremer's support index), distance analysis (bootstrap percentage), and maximum-likelihood (reliability percentages). The tree was rooted by the two primate sequences.

firms the Myodonta concept (Schaub, in Grassé, 1955) including the Dipodidae and Muridae families (node F with BP of $96 \%$ and BSI of +8 ). The weighted-parsimony analysis with the stepmatrix (taking into account a different saturation level for each kind of substitution) did not show any interesting difference with regard to the classical parsimony analysis (compare BP values for MP and MPw in Table 3). To the contrary of other studies with mitochondrial genes (Hassanin et $a l ., 1998 \mathrm{a}, \mathrm{b}$ ), this a priori weighting did not improve the robustness of the maximum-parsimony tree.

Reliability percentages (ML analysis with $\alpha$ estimated at 0.38 and estimated proportion of invariant sites of 0.0 ) and bootstrap percentages ( $\mathrm{NJ}$ with $\alpha=$ 0.38 according to the puzzle analysis) yield results similar to those obtained with the parsimony analysis (Table 3). All the ancestral segments that were strongly supported through parsimony are also retrieved with a high robustness by the two other optimality criteria.

We checked that the Myodonta support was not due to the particular taxonomic sampling of our data set, especially with regard to differences between the Dipodidae (5 species) and the Muridae (29 species) rep- 


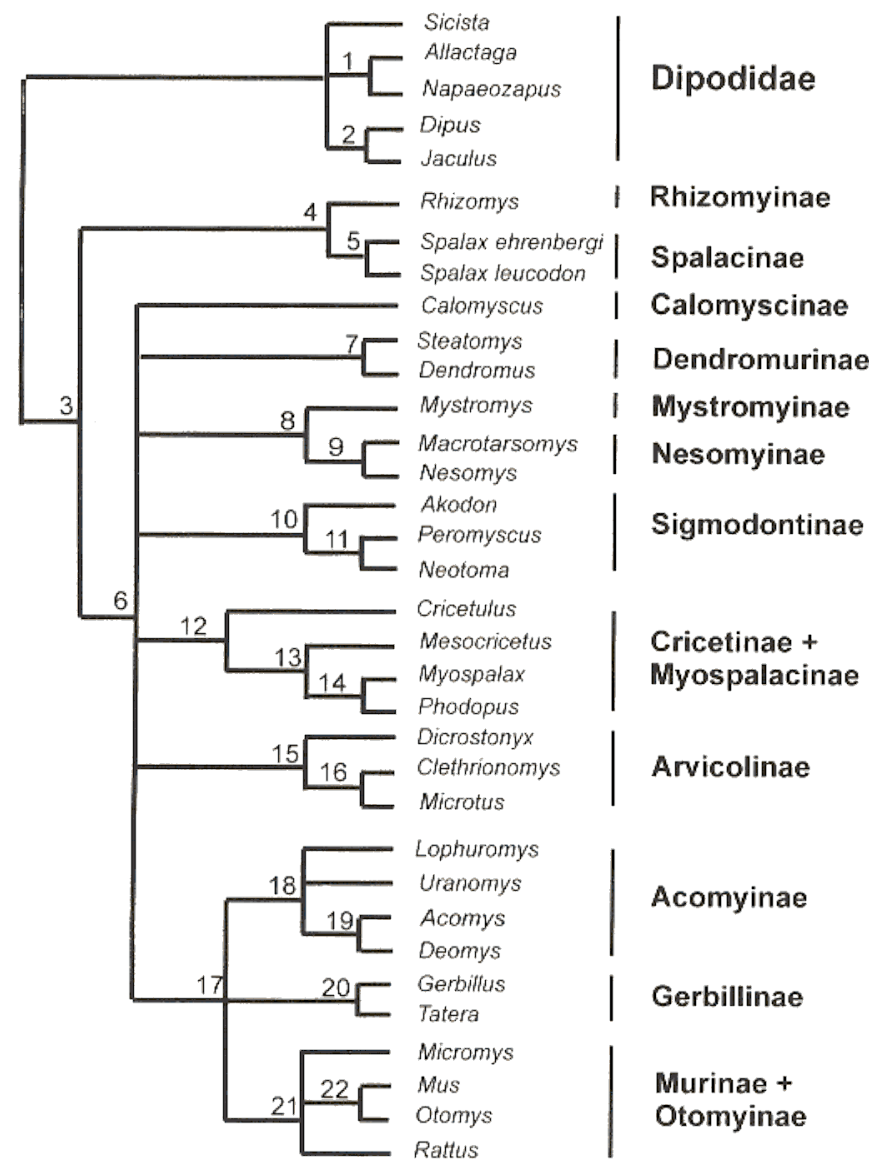

FIG. 2. Synthetic tree summarizing the results derived from three approaches on 34 Myodonta DNA sequences of the LCAT gene. The robustness of each node (labeled 1 to 22 ) is documented in Table 4 for maximum-parsimony (bootstrap percentage and Bremer's support index), distance analysis (BP), and maximum-likelihood (reliability percentages). The tree was rooted by five Dipodidae sequences.

resentations. Distance analysis (Tamura-Nei, $\alpha=$ 0.38 ) was repeated 10 times with a random sample of five Muridae sequences, and the robustness of nodes was addressed by bootstrap. The average BP was 87.2 for Myodonta (SD 9.9, range 74-98), 92.7 for Dipodidae (SD 5.2, range 82-98), and 93.9 for Muridae (SD 8.8, range 76-100). Thus, we feel confident that the Myodonta clade is robust and reliable and that this node does not rely upon a particular choice of its representative taxa.

\section{Analyses with Dipodidae only as Outgroup}

As shown by the previous analysis, the Myodonta monophyly, as well as the naturalness of Dipodidae and Muridae, appears well established. Thus, for the purpose of avoiding the use of too-distant outgroups with regard to within-Muridae relationships, we performed a second set of analyses using only the five Dipodidae as outgroup for a monophyletic Muridae (Fig. 2 and Table 4).
Maximum-parsimony. The parsimony reconstruction based on equal weighting of each nucleotide substitution yielded eight most-parsimonious trees. Each tree is 1096 steps long, with a consistency index (excluding uninformative characters) of 0.40 and a retention index of 0.53. Figure 2 indicates that, within Muridae, the first dichotomy isolates a clade (node 4 in Table 4) comprising Spalax and Rhizomys. The remaining Muridae comprise a strongly supported clade (BP of 92\% and BSI of +8 : node 6). The monophyly of several subfamilies represented by at least two genera is robust: Nesomyinae (node 9), Arvicolinae (node 15), and Gerbillinae (node 20) are supported by BPs between 84 and $100 \%$ and by BSIs between +7 and +12 . On the contrary, as was already observed by Robinson et al. (1997), the New World rats and mice, Sigmodontinae (node 10), represented in this study by Peromyscus, Neotoma, and Akodon, are poorly defined (BP of $45 \%$ and BSI of +1 ). Maximum-parsimony analysis also clearly shows (BP of $98 \%$ and BSI of +9 ) that Acomys, Uranomys, and Lophuromys do not belong to the true Murinae (represented here by Mus, Rattus, Micromys) but are clustered in a suprageneric clade

\section{TABLE 4}

Indices of Robustness for the Nodes of the Phylogenetic Tree with Myodonta Only Represented in Fig. 2 Using Maximum-Parsimony (MP), Distance, and Maximum-Likelihood (ML) Analyses

$\begin{array}{rrrrrr}\text { Nodes } & \text { MP } & \text { MP } & \text { BSI } & \text { NJ } & \text { ML } \\ 1 & 89 & 96 & +4 & 82 & 94 \\ 2 & 88 & 81 & +4 & 85 & 94 \\ 3 & 100 & 100 & +10 & 100 & 83 \\ 4 & 67 & 51 & +2 & 96 & 96 \\ 5 & 100 & 100 & +12 & 100 & 98 \\ 6 & 92 & 93 & +8 & 91 & 70 \\ 7 & 84 & 68 & +6 & 93 & 87 \\ 8 & 90 & 92 & +6 & 90 & 49 \\ 9 & 66 & 56 & +2 & 71 & 34 \\ 10 & 45 & 51 & +1 & 65 & 82 \\ 11 & 51 & 51 & +1 & 57 & 65 \\ 12 & 97 & 93 & +7 & 97 & 75 \\ 13 & 79 & 71 & +2 & 76 & 72 \\ 14 & 88 & 76 & +4 & 61 & 75 \\ 15 & 97 & 99 & +12 & 99 & 88 \\ 16 & 96 & 98 & +7 & 99 & 93 \\ 17 & 65 & 60 & +4 & 59 & 25 \\ 18 & 98 & 98 & +9 & 99 & 68 \\ 19 & 94 & 96 & +6 & 89 & 72 \\ 20 & 100 & 100 & +10 & 100 & 95 \\ 21 & 99 & 100 & +9 & 100 & 77 \\ 22 & 99 & 99 & +8 & 99 & 92\end{array}$

Note. As in Fig. 1, bootstrap percentages computed after standard MP (with equal weighting), MP weighted by slopes of saturation profiles $\left(\mathrm{MP}_{\mathrm{w}}\right)$, and neighbor joining $(\mathrm{NJ})$ on Tamura and Nei (1993) distances with gamma rates (alpha $=0.41$ ) are reported. Reliability percentages deduced from the quartet puzzling ML methods are also given. Finally, Bremer support indices (BSIs) are indicated. 
(node 18), which also includes Deomys (traditionally classified with Dendromurinae). Following Hänni et al. (1995, p. 132), we name "acomyines" or [provisionally] "Acomyinae" as the clade containing the genera Acomys, Deomys, Lophuromys, and Uranomys.

A new finding for nonmorphological studies of murid systematics is the nesting of Myospalacinae within Cricetinae (BP characterizing Cricetinae + Myospalacinae of $97 \%$; BSI of +7 ) (node 12). As previously shown by Chevret et al. (1993b), Otomyinae (Otomys) is included within Murinae (as the sister genus of Mus: node 22) with a strong support: BP of $99 \%$ and BSI of +8 . The ancestral segment (numbered 8 in Table 4 and Fig. 2) uniting the Malagasy Nesomyinae (represented by Nesomys and Macrotarsomys) with the South African Mystromyinae (represented by Mystromys) is strongly supported (BP of $90 \%$ and BSI of +6 ). Finally, parsimony suggests a clade comprising Murinae, Gerbillinae, and "Acomyinae" (node 17), although with a poor support (BP of $60-65 \%$ and BSI of +4).

The weighted parsimony analysis (with stepmatrices) gave approximately the same values as the unweighted analysis and did not improve the robustness of the inferences (compare columns MP and Mpw in Table 4). An unexpected observation was that some nodes were less supported (i.e., for node 7: BP of $84 \%$ for equal weighted analysis and $68 \%$ for weighted analysis) when saturation was taken into account.

Neighbor-joining and maximum-likelihood. The clustering of Spalacinae and Rhizomyinae as the earliest offshoot from murid ancestors was strongly supported by NJ and ML analyses (respectively, BP and RP of 96\%), compared to the poor robustness observed through maximum-parsimony methods (node 4 in Table 4). Similarily, the monophyly of Sigmodontinae is also more robust with maximum-likelihood ( $\mathrm{RP}=82 \%$ ). For the NJ analysis, branching patterns and bootstrap values were similar using either MUST or PAUP. The use of the Tamura and Nei (1993) model of substitution along with a mixed model of among-sites rate heterogeneity could explain the better performances of distance and likelihood optimality criterions, because such approaches take into account the heterogeneities existing in the data matrix. The higher (Rhizomys) or slower (Sigmodontinae) rates of evolution characterizing some of these taxa (see below) could also explain the relative difference in robustness between maximum-parsimony and other approaches. All other nodes that were strongly supported through maximum-parsimony analysis are also retrieved as strong ancestral segments in the maximum-likelihood and distance results (Table 4).

The highest-likelihood tree $(\operatorname{lnL}=-6687.93)$ on 34 Myodonta species was identified with PUZZLE (Strimmer and Von Haeseler, 1996) among 945 alternative trees constructed using MOLPHY 2.3b3 (Adashi and Hasegawa, 1996). This tree has the same topology as previously obtained by the distance and parsimony criteria.

Likelihood alternatives to the best tree. The highestlikelihood tree was used as the reference topology to apply the test of Kishino and Hasegawa (1989) for assessing the following clades: (1) the monophyly of each of the "Acomyinae" and Sigmodontinae groups; (2) the sister group relationships between (a) Mystromyinae and Nesomyinae and (b) Gerbillinae, Murinae, and "Acomyinae;" and (3) the nested position of (a) Otomyinae within Murinae and (b) Myospalacinae within Cricetinae.

For doing so, we tested different alternative topologies derived from traditional morphological and paleontological studies or from various molecular hypotheses: Acomys, Uranomys, and Lophuromys in Murinae (Carleton and Musser, 1984; Musser and Carleton, 1993); Deomys in Dendromurinae (Carleton and Musser, 1984; Musser and Carleton, 1993); Peromyscus (Sigmodontinae) with Clethrionomys (Arvicolinae) (Dickerman, 1992); Neotoma (Sigmodontinae) with Eurasian Cricetinae (Dickerman, 1992); Myospalax with Spalax and Rhizomyinae (Miller and Gidley, 1918); Mystromys with Cricetinae (Carleton and Musser, 1984); Otomys as the sister taxon of Murinae (Thomas, 1896; Misonne, 1971; Chaline et al., 1977); Murinae, Gerbillinae, and Acomyinae paraphyletic (Ameur, 1984; Flynn et al., 1985).

All these alternative topologies exhibited a significantly worse log-likelihood than the one measured for the highest-likelihood tree. Based on these tests, we maintain the previously mentioned relationships, in particular the monophyly of each of the two subfamilies "Acomyinae" and Sigmodontinae and the inclusion of Otomyinae and Myospalacinae within Murinae and Cricetinae, respectively.

\section{Relative-Rate Tests}

To identify whether differences in rates of LCAT change existed in the major taxa of rodents (Gliridae, Sciuridae, Dipodidae, Muridae, and Caviomorpha), relative-rate tests were conducted with each of them against the remaining lineages. $K_{s}$ comparisons did not evidence significant differences in relative rate in the different groups. To the contrary, $K_{a}$ comparisons (nonsynonymous changes) showed marked differences in evolutionary rates: Dipodidae and Sciuridae appear to be slowly evolving taxa (respectively, $P<0.001$ and $P<0.03$ ). Among Sciuridae, more detailed analyses showed that only Marmota had a slow rate of evolution $(P<0.003)$. On the other hand, within Dipodidae, four of the five studied species showed a significantly lower rate of nonsynonymous change (Sicista, Jaculus, Dipus, and Napaeozapus $)(P<0.01)$. Muridae as a whole did not have a particularly fast rate of evolution.

Relative-rates tests were then performed among Muridae using the slowly evolving Dipodidae as out- 
TABLE 5

Estimations of the Separation Times of Different Events within the Muroids, on the Basis of the Molecular Data

\begin{tabular}{|c|c|c|c|c|c|}
\hline Separation events & $\begin{array}{l}\text { Calibration point } \\
\text { based on the } \\
\text { separation: } \\
\text { Spalax/modern } \\
\text { muroids (in Myr) }\end{array}$ & SE & $\begin{array}{l}\text { Calibration } \\
\text { point based on } \\
\text { the separation: } \\
\text { Mus / Rattus } \\
\text { (in Myr) }\end{array}$ & SE & Paleontological estimations \\
\hline Spalax/modern muroids & 20 & & 21.7 & 1 & $\begin{array}{l}20 \text { Myr (Hugueney and } \\
\text { Mein, 1993) }\end{array}$ \\
\hline Mus/Rattus & 11.5 & 1 & 12 & & $\begin{array}{l}12 \mathrm{Myr} \text { (Jaeger et al., 1986; } \\
\text { Jacobs and Down, 1994) }\end{array}$ \\
\hline Gerbillus/Tatera & 7.8 & 1 & 8.8 & 1.1 & 8-10 Myr (Tong, 1989) \\
\hline Clethrionomys/Microtus & 7.4 & 0.7 & 8 & 0.8 & $\begin{array}{l}\text { 3, 5-6 Myr (Chaline and } \\
\text { Graf, 1988) }\end{array}$ \\
\hline Myospalax/Phodopus & 4.5 & 0.7 & 5 & 0.7 & $\begin{array}{l}2 \mathrm{Myr} \text { (Chaline et al., 1977; } \\
\text { Carleton and Musser, } \\
\text { 1984) }\end{array}$ \\
\hline Radiation of modern muroids & 16.8 & 0.5 & 19 & 0.5 & $\begin{array}{l}18 \mathrm{Myr} \text { (Tong and Jaeger, } \\
1993 \text { ) }\end{array}$ \\
\hline Steatomys /Dendromus & 9.5 & 1.3 & 10.7 & 1.4 & $\begin{array}{l}\text { 8-11 Myr (McKenna and } \\
\text { Bell, 1997) }\end{array}$ \\
\hline Gerbillinae/Murinae/Acomyinae & 15.4 & 0.7 & 16.6 & 0.7 & $\begin{array}{l}16 \text { Myr (Tong and Jaeger, } \\
1993 \text { ) }\end{array}$ \\
\hline
\end{tabular}

Note. The numbers in boldface correspond to the two calibration points used for this analysis: $20 \mathrm{Myr}$ for the separation between Spalacinae and modern Muroids (Hugueney and Mein, 1993); 12 Myr for the separation between Mus and Rattus (Jacobs et al., 1986; Jacobs and Down, 1994). SE, standard error.

group. As previously, synonymous ( $\mathrm{K}_{\mathrm{s}}$ values) changes did not show significant differences between the different Muridae subfamilies. However, $\mathrm{K}_{\mathrm{a}}$ comparisons showed that Nesomyinae and Sigmodontinae were slowly evolving (respectively, $P<0.05$ and $P<$ $0.002)$ and that Rhizomyinae was rapidly evolving $(P<0.02)$. Within Malagasy rodents, further analyses showed that only Nesomys had a lower rate of evolution. Within New World Sigmodontinae, all three genera (Neotoma, Peromyscus, and Akodon) were significantly slowly evolving (respectively, $P<0.001, P<$ 0.05 , and $P<0.02$ ).

The different results obtained for $\mathrm{K}_{\mathrm{s}}$ and $\mathrm{K}_{\mathrm{a}}$ can be explained by the fact that synonymous substitutions saturate at the suprafamilial level, as was already suggested by the saturation analysis (see above and Table 2).

Consequently, to apply a molecular clock and estimate dates of separation between the murid genera and the subfamilies, we performed another maximumlikelihood analysis with Dipodidae as outgroup and all the Muridae except the slowest and fastest evolving species (Nesomys, all Sigmodontinae, and Rhizomys). The inferred maximum-likelihood distances were the basis for estimating separation times. Two calibration points derived from paleontological data were chosen: (1) the Mus/Rattus dichotomy set at 12 millions years before present (Mybp) (Jaeger et al., 1986; Jacobs et al., 1989. 1990: Jacobs and Down. 1994) and (2) the sepa- ration time between Spalacinae and all the remaining living Muridae estimated at approximately 20 Mybp (Hugueney and Mein, 1993). The ML distance between Mus and Rattus is 0.047 , whereas that between Spalax and all remaining murids is 0.085 . These values give a rate of 0.0039 (Mus/Rattus) or 0.0042 (Spalax/other Muridae) ML distance per million years. When these rather similar rates are applied to the different dichotomies within Muridae, the following molecular datings are obtained: 16.8 to 19 Mybp for the initial bushlike radiation; 15.4 to $16.6 \mathrm{Mybp}$ for the separation between Murinae, Gerbillinae, and Acomyinae; 7.8 to $8.8 \mathrm{Mybp}$ between the gerbil genera Gerbillus and Tatera; 4.5 to 5.0 Mybp between the hamster Phodopus (Cricetinae) and the zokor Myospalax; 7.4 to 8.0 Mybp between the voles Microtus and Clethrionomys; and 9.5 to 10.7 Mybp between the two dendromurines Steatomys and Dendromus. Table 5 provides these values and their $\mathrm{SE}$ in comparison to paleontological estimates.

\section{DISCUSSION}

\section{Molecular Evolutionary Rates}

As for another nuclear protein-coding gene which was sequenced in representatives of several rodent families (exon 28 of von Willebrandt Factor gene: $\mathrm{Hu}-$ chon et al., 1999), LCAT sequences show that Muridae are not especially rapidly evolving mammals. This re- 
sult contrasts with results of other nuclear (DNA/DNA hybridization; Catzeflis et al., 1987; sequences: Li et al., 1987) and mitochondrial (Philippe, 1997) studies, most of them comparing a few murids with nonrodent eutherian mammals. According to Huchon et al. (1999) and Robinson et al. (1998), part of "this result is probably the consequence of the use of a "topology-weighted" procedure in the computation of the relative-rate test." Another reason could be that the previous studies analyzed only a limited number of Muridae subfamilies (at most Murinae, Cricetinae, and Arvicolinae; Catzeflis et al., 1987; O'hUigin and $\mathrm{Li}, 1992$ ) or, most commonly, just the two laboratory-bred murines Mus and Rattus.

Thus, our study indicates that, if a sufficient sampling of Muridae representatives is considered, this speciose family will exhibit both slowly evolving (Sigmodontinae) and rapidly evolving (Rhizomys) taxa. Consequently, in comparison with other rodent families (Sciuridae, Gliridae, etc.), murids on average do not appear to have a particular pattern of evolution.

\section{Relationships between Dipodidae and Muridae: the Myodonta Concept}

The concept of a sister group relationship between Dipodidae and Muridae was proposed for the first time by Schaub (in Grassé, 1955) on the basis of morphological characters, uniting these taxa into the infraorder Myodonta. Later, in a comparative myological study, Klingener (1964) evidenced two exclusive synapomorphies for the taxon Myodonta: the lack of differenciation of Musculus adductor magnus into $M$. adductor minimus and $M$. adductor magnus proprius and the separation of $M$. femorococcygeus from $M$. biceps femoris by the posterior femoral cutaneous nerve. Other embryological (see review in Luckett and Hartenberger, 1985) and molecular (Serdobova and Kramerov, 1998) studies confirmed the taxonomic value of this infraorder.

However, until now, nuclear (VWF gene; Huchon et $a l ., 1999$ ) and mitochondrial (12S rDNA; Nedbal et al., 1996) sequences gave a weak support for the monophyly of this infraoder. Thus, the phylogenetic signal of the LCAT gene, which strongly clusters Dipodidae and Muridae, gives additional support to the morphological hypothesis for the Myodonta.

\section{An Early Isolation of Spalacinae and Rhizomyinae and an Explosive Radiation Leading to the Remaining Modern Muridae Subfamilies}

As already shown in Robinson et al. (1997), our results confirm the hypothesis derived from the fossil record of an early separation of Spalacinae and Rhizomyinae from other Muridae (Flynn et al., 1985; Flynn, 1990, Hugueney and Mein, 1993). The LCAT molecular clock (calibrated on the basis of the Mus/Rattus dichot- omy at $12 \mathrm{Mybp}$ ) suggests that this separation occurred approximately $20 \mathrm{Mybp}$, a dating in good agreement with paleontological inferences (Flynn et al., 1985; Hugueney and Mein, 1993; Mein and Ginsburg, 1997). Thus, this study clearly identifies mole rats, Spalacinae, and bamboo rats, Rhizomyinae, as the sister group of all remaining murid families, and this result conflicts with Jansa et al. (1999), who made the a priori choice of Calomyscus for rooting several subfamilies of African and Asian murids.

The remaining 12 subfamilies are clustered together in a strongly supported clade (node 6 on Fig. 2). The first branching event of this clade is a large polytomy, leading to seven lineages, of which three encompass more than 1 subfamily: Mystromyinae and Nesomyinae (node 8: Fig. 2 and Table 4), Cricetinae and Myospalacinae (node 12), and Murinae, Otomyinae, Gerbillinae, and Acomyinae (node 17). Thus, most of the "advanced" murid subfamilies appear to be of a polytomous origin, indicating the phenomenon of a spectacular bushlike radiation having led to the majority of them. Because ancestral segments with high bootstrap support are retrieved deeper into the trees of Fig. 1 (node H: Muroidea; node F: Myodonta) and Fig. 2 (node 3: Muridae), our inference for the existence of this radiation is probably real and not due to artifacts related to saturation and homoplasy. On the basis of the molecular data, this event occurred 17-19 Mybp (Table 5). This approximation is in accordance with the fossil records (Hartenberger, 1985; Baskin, 1986; Jacobs et al., 1989; Tong and Jaeger, 1993); the oldest fossils considered direct ancestors of living murids, such as Potwarmus thailandicus, are dated ca. 18 Mybp (Mein and Ginsburg, 1997). Other molecular studies (DNA/ DNA hybridization: Catzeflis et al., 1993; nuclear LCAT gene: Robinson et al., 1997) have also estimated this radiation at $\approx 18 \mathrm{Mybp}$. According to Aguilar et al. (1996, 1999), this period (end of early Miocene) was characterized by changes of climate, which favored the spread in Europe, northern Africa, and the Middle East of allochtonous groups such as the extinct cricetid rodents (Democricetodon), probably coming from Asia. It is also during this period of time that other cricetid rodents (Afrocricetodontinae) invaded, coming from Asia, the other African regions, and Madagascar, leading later to the appearance of modern African subfamilies (Lophiomyinae, Cricetomyinae, Dendromurinae, Nesomyinae, Mystromyinae) (Lavocat, 1973, 1978; Bernor et al., 1987). Concerning the New World, the extinct genus Copemys, a taxon related to Democricetodon (see discussion in Carleton and Musser, 1984), migrated at the end of early Miocene (Flynn et al., 1985) from the Palearctic to North America, where it flourished and gave rise to the ancestors of Sigmodontinae (Martin, 1980; Carleton and Musser, 1984); Baskin (1986) describes Abelmoschomys simpsoni, a fossil dated at ca. $9 \mathrm{Mybp}$, as the oldest direct ancestor 
for the living New World rats and mice. Thus, combining our molecular evidence with paleontological data and interpretations, we suggest that the early Miocene bushlike radiation of Muridae was associated with and immediately followed by a large worldwide spread of several ancestral Asiatic cricetid rodents.

\section{A Sister Group Relationship among Murinae, Gerbillinae, and Acomyinae}

Traditional paleontological hypotheses never classified or associated Gerbillinae with Murinae (Simpson, 1945; Chaline et al., 1977; de Graaf, 1981; Ameur, 1984; Flynn et al., 1985), most probably because their dental patterns are so different. A comparative chromosomal study (Viegas-Pequignot et al., 1986) supported this view, arguing that a greater similarity in karyotypes was observed among Murinae, Cricetinae, and Sigmodontinae than between any of these and Neotominae, Nesomyinae, Arvicolinae, and Gerbillinae. Molecular studies based on 12S rRNA sequences (Hänni et al., 1995; Dubois et al., 1996) also suggested that Gerbillinae were external to a clade uniting Cricetinae + Murinae. Nevertheless, this topology might have been the result of homoplasy related to the combination of a rapidly evolving mitochondrial gene with a too-distant outgroup (Gliridae only, in these references).

Although the resampling support is weak (BP values between 59 and 65: node 17 in Table 4), our results tentatively suggest that Gerbillinae, "Acomyinae," and Murinae had a more recent common ancestor with regard to the other Muridae subfamilies. The robustness of this cluster improves when LCAT sequences are combined with 12S rRNA data (BP of $86 \%$ and BSI of 11 in MP; P. Chevret et al., unpublished); similarily, the Kishino and Hasegawa test (1989) also confirms a closer relationship between these three subfamilies.

This result is congruent with DNA/DNA hybridization studies (Brownell, 1983; Chevret et al., 1993a, unpublished; Catzeflis et al., 1992, 1993). From a paleontological point of view, recent studies (Jaeger et al., 1985; De Bruyn and Hussain, 1985; Tong, 1989; Tong and Jaeger, 1993) proposed the separation of Gerbillinae and Murinae from a common ancestor at $\approx 16-18$ Mybp. According to these authors, this event appeared 2 millions years after an initial separation from other cricetid muroids. This paleontological scenario is in accordance with the divergence times estimated in the molecular analyses (Table 5), namely 15.4 to 16.6 Mybp for the Gerbillinae/Murinae split, subsequent from the initial radiation of modern muroids set at 16.8 to 19.0 Mybp.

Thus, our molecular results give some evidence for confirming a sister group relationship among Gerbillinae. Murinae. and "Acomvinae." implving a later sen- aration between them with regard to the other subfam. ilies of Muridae.

\section{The Existence of an Acomyine Group and the Paraphyly of Dendromurinae}

The LCAT gene study confirms with much robustness that Acomys, Lophuromys, Uranomys, and Deomys are clustered in a suprageneric clade, which we call the "Acomyinae" group. This inference is in agreement with previous molecular data (Chevret et al., 1993a; Furano et al., 1994; Hänni et al., 1995; Verheyen et al., 1996; Dubois et al., 1999), which considered a reduced taxonomic sampling pertaining to this question. However, a monophyletic acomyine subfamily is seriously at odds with traditional systematics based on comparative morphoanatomy (no morphological signature is known for this group, especially considering the inclusion of Deomys).

The separation between Deomys and the two other studied Dendromurinae (Dendromus and Steatomys) provides additional evidence for the paraphyly of this subfamily, as already suggested by Denys et al. (1995) and Verheyen et al. (1996) through comparative morphology and molecular data.

\section{Otomyinae Are Nested within Murinae}

As already shown by other molecular (Chevret et al., 1993b, unpublished; Usdin et al., 1995) and paleontological (Senegas and Avery, 1998) studies, we confirm a close relationship between Otomyinae (represented by Otomys) and Murinae. This result and results of morphological studies (Chevret et al., 1993b; Senegas and Avery, 1998) suggest that this subfamily should be invalidated and that the Otomyinae should be considered a tribe of Murinae, despite the tremendous differences in the dental patterns of vlei and karoo rats with regard to the remaining Old World rats and mice.

\section{An African Origin for the Malagasy Nesomyinae}

Our results strongly suggest a sister group relationship between the two Malagasy Nesomyinae genera and the South African Mystromyinae. This result is congruent with the hypothesis of Lavocat $(1973,1978)$ who proposed to ally Nesomyinae with other archaic African groups such as Mystromyinae, Cricetomyinae, and Lophyomyinae; Chaline et al. (1977) united these taxa into the family Nesomyidae. Indeed, all these murids would represent derivatives of an old African cricetodontine stock. On the basis of morphological characters, Carleton and Musser (1984) also proposed the association of the white-tailed hamster, Mystromys, with Nesomyinae. However, other molecular studies suggested that the more recent relatives of Nesomyinae were Cricetomyinae (12S rRNA: Dubois et $a l ., 1996)$ or Murinae (cytochrome $b$ gene: Jansa et al., 1999). Nevertheless. hoth our and Duhnis's ot al. (1996) 
studies suffer from a poor taxonomic sampling with regard to Nesomyinae representation. Sequences of Cricetomyinae could not be obtained for the LCAT gene. On the other hand, the results and interpretations of Jansa et al. (1999) remain doubtful for two reasons: their outgroup taxon (Calomyscus) was not adequate to root the different Asian and African subfamilies and most of the cytochrome $b$ variation at such suprageneric levels is random homoplasy due to saturation (data not shown). Clearly, more analyses are needed for clarifying these relationships, especially sampling, through moderately evolving genes (such as nuclear LCAT or nonsynonymous substitutions in mitochondrial genes), additional taxa of Cricetomyinae (Cricetomys, Beamys, and Saccostomus) and of Nesomyinae.

\section{Are the New World Rats and Mice Paraphyletic?}

New World rats and mice have been occasionally grouped together with Palearctic hamsters in the family Cricetidae (Ellermann, 1941; Simpson, 1945). Later, other paleontologists and morphologists proposed to separate the New World species as a distinct subfamily (Hesperomyinae of Chaline et al., 1977), whose name is Sigmodontinae (Reig, 1980; Carleton and Musser, 1984). Moreover, Hooper and Musser (1964) divided this speciose subfamily (about 80 genera) into two groups according to the morphology of the glans penis: a simple type, characteristic of North American species and a complex type distributed among South American species. These two morphological archetypes led to distinct two tribes: the North American Peromyscini and the South American Sigmodontini. In 1980, Reig proposed to designate the tribes as subfamilies: Neotominae and Sigmodontinae, respectively. However, Carleton (1980) cautioned that "formal recognition of the two assemblages as subfamilies had not been convincingly demonstrated." On the basis of DNA/DNA hybridization, Dickerman (1992) and Catzeflis et al. (1993) confirmed a phylogenetic dichotomy between North American and South American cricetids and proposed to consider them two distinct subfamilies.

Our data involve only three genera, but they confirm, although with a weak support, the monophyly of the New World Sigmodontinae. Based on a large taxonomic sampling of 38 South American and 4 North American genera of Sigmodontinae, Smith and Patton (1999) evidenced a weak support for the monophyly of the group based on the mitochondrial cytochrome $b$ gene. For the LCAT gene, the alternative topologies contradicting this monophyly always exhibit significantly worse log-likelihood, suggesting confirmation of the Sigmodontinae concept. Moreover, the fact that all three Sigmodontinae examined here are characterized by a slower rate of DNA change corroborates this hypothesis.
A Close Relationship between Palearctic Myospalacinae and Cricetinae

Owing to their particular morphology, the Myospalacinae have been associated with other groups of fossorial rodents such as the mole rats, Spalacidae (Miller and Gidley, 1918), or the bamboo rats, Rhyzomyinae (Tullberg, 1899). Later, Chaline et al. (1977) preferred to consider this group as a distinct subfamily and proposed that they evolved from Eurasian cricetodontines during the Pleistocene. In the same way, Carleton and Musser (1984) concluded that Myospalax "is a primitive cricetid that probably became fossorially adapted before the Gobi region became arid." Our results indicate that Myospalacinae are nested within Cricetinae (particularly with the Asiatic species Phodopus) (see Table 4 and Fig. 2). For this reason, we propose to invalidate this subfamily and to consider the genus Myospalax (sole living member of "Myospalacinae") as defining a tribe among the subfamily Cricetinae. Moreover, the divergence time estimation based on our molecular data suggests that the separation between Myospalax and the other Cricetinae appeared during Early Pliocene (4-5 Mybp). Until recently, the oldest fossils attributed with confidence to zokors were at most of Upper Pliocene (ca. 2 Mybp: Lawrence, 1991). The synthesis by Zheng (1994) documented the fossil Episiphneus sinensis, dated at ca. $4 \mathrm{Mybp}$, as the direct ancestor for living Myospalax spp., thus a temporal estimate in good agreement with the molecular dating of this study. Inferences from the LCAT gene disagree with Lawrence's (1991, p. 282) opinion by which "the equal division of [morphological] characters between plesiomorphic murid features and derived characters associated with fossorial adaptation lends support to the proposal that myospalacines are derived from a primitive murid stock. ..."

\section{Differences between Datings Estimated by Fossils and Molecules}

Although most of the separation times estimated on the basis of the molecular data are in good agreement with those obtained through the fossil records (Table 5), one seems unclear. The value of 7.4 to $8.0(\mathrm{SE}=0.8)$ Mybp for the split between the vole genera Clethrionomys and Microtus is much older than the dating at 3.5 to 6.0 Mybp suggested by Chaline and Graf (1988). Our estimate is similar to that calculated by Robinson et al. (1997), also obtained with the nuclear LCAT gene, but is at odds with other molecular studies based on DNA/ DNA hybridization (Catzeflis et al., 1987) or on the nuclear ribonuclease gene sequences (Dubois et al., 1999). The relative-rate tests for LCAT showed that the two vole taxa do not evolve at a particular rate of evolution with regard to the other Muridae. Thus, the molecular clock of the LCAT gene seems also valid for these arvicoline taxa. In conclusion. we suggest that 
additional taxa related to the Microtus/Clethrionomys divergence should be examined for their molecular divergence to confirm our 6.5 to $8 \mathrm{Mybp}$ dating. If that dating is confirmed, the interpretation of the fossil record leading to the paleontological estimate (3.5 Mybp) should be reconsidered.

\section{CONCLUSIONS}

This molecular study was performed on a nuclear gene sequenced for representatives of 13 of 17 Muridae subfamilies and 4 of 7 Dipodidae subfamilies. This taxonomic sampling led us to confirm the Myodonta infraorder including Muridae and Dipodidae. Within the largest mammalian family, Muridae, the use of the LCAT gene evidenced the following results: (1) that murids do not have a faster-evolving rate of change with regard to other rodents such as glirids, sciurids, or caviomorphs; (2) the monophyly of several subfamilies including the Spalacinae, Nesomyinae, Cricetinae, Arvicolinae, Gerbillinae, and Sigmodontinae; this result is nevertheless preliminary, as most of these taxa were represented by too few genera in this study; (3) that Myospalacinae (fossorial zokors) should be invalidated and considered a tribe of Cricetinae; in the same way, we propose to abandon the subfamilial rank for Otomyinae and to include them as a tribe within Murinae; (4) the confirmation of the Acomyinae subfamily, which comprises genera previously classified in Murinae (Acomys, Lophuromys, and Uranomys) or in Dendromurinae (Deomys); as a consequence, the traditional Murinae and Dendromurinae (as of Carleton and Musser, 1984; Musser and Carleton, 1993) are paraphyletic and/or polyphyletic; (5) the following sister group relationships: (a) Spalacinae and Rhizomyinae, which were early separated from all other Muridae; (b) African Mystromyinae and Malagasy Nesomyinae; this relationship should be further tested by including other African archaic murids such as Petromyscus and Cricetomyinae; and (c) Murinae, Gerbillinae, and Acomyinae; and (6) that, when calibrated by two paleontological data sets within muroids, the datings of different separation events estimated on the basis of molecular data confirm those documented by the fossil record.

Finally, our results strongly suggest that there has been a bushlike radiation, $\approx 18$ Mybp, leading to the majority of the Muridae subfamilies. This interpretation should now be tested by the use of another nuclear gene, encompassing a similar biodiversity for an adequate representation of this speciose family.

\section{ACKNOWLEDGMENTS}

This research was funded by a grant from the European Community Project ERB-FMRX-CT98-0221. We thank all people who provided tissue samples of rodent taxa that they collected, often in remote countries: Marina Baskevitch, Gary Bronner, Giancarlo Contrafatto, D. Bellars, Jean-Marc Duplantier, Piotr Gambarian, JeanClaude Gautun, Laurent Granjon, I. Hansmann, Rolf Anker Ims, Petros Lymberakis, Daniel Rakotondravony, Marco Salvioni, Majad Zadé, and Vitaly Volobouev. Thanks are also expressed to Emmanuel Douzery, Dorothée Huchon, Pascale Chevret, Jean-Jacques Jaeger, Jacques Michaux, and Jean-Louis Hartenberger for their helpful discussions about analyses of saturation, relative-rate tests, and the phylogeny of Muridae. A special thanks to Marie-Claire Beckers and Corinne Lautier for their advise in automatic sequencing and to Professor F. Gricorescu (Institut Universitaire de Recherche Clinique, Montpellier) for the use of his automatic sequencer. This is contribution ISEM 2000-098 of Institut des Sciences de l'Evolution de Montpellier (UMR 5554 CNRS-Université Montpellier II).

\section{REFERENCES}

Adachi, J., and Hasegawa, M. (1996). MOLPHY: Programs for molecular phylogenetics Version 2.3 edit. Institute of Statistical Mathematics, Tokyo.

Aguilar, J. P., Clauzon, G., de Goer de Herve, A., Maluski, H., Michaux, J., and Welcomme, J. L. (1996). The MN3 fossil mammalbearing locality of Beaulieu (France): Biochronology, radiometric dating, and lower age limit of the Early Neogene renewal of the mammalian fauna in Europe. Newsl. Stratigr. 34: 171-191.

Aguilar, J. P., Escarguel, G., and Michaux, J. (1999). A succession of Miocene rodent assemblages from fissure fillings in southern France: Palaeoenvironmental interpretation and comparison with Spain. Palaeogeogr.- Palaeoclimat. Palaeoecol. 145: 215-230.

Ameur, R. (1984). Découverte de nouveaux rongeurs dans la formation miocène de Bou Hanifia (Algérie Occidentale). Géobios 17: 165-175.

Baskin, J. A. (1986). The late Miocene radiation of Neotropical sigmodontine rodents in North America. Contr. Geol. Univ. Wyoming Special Paper 3: 287-303.

Bernor, R. L., Brunet, M., Ginsburg, L., Mein, P., Pickford, M., Rögl, F., Sen, S., Steininger, F., and Thomas, H. (1987). A consideration of some major topics concerning Old World Miocene mammalian chronology, migrations and paleogeography. Geobios 20: 431-439.

Bremer, K. (1988). The limits of amino acid sequence data in angiosperm phylogenetic reconstruction. Evolution 42: 795-803.

Brownell, E. (1983). DNA/DNA hybridization studies of muroid rodents: Symmetry and rates of molecular evolution. Evolution 37: 1034-1051.

Carleton, M. D. (1980). Phylogenetic relationships in neotomineperomyscine rodents (Muroidea) and a reappraisal of the dichotomy within New World Cricetinae. Misc. Publ. Univ. Michigan 157: 1-146.

Carleton, M. D., and Musser, G. G. (1984). Muroid rodents. In "Orders and Families of Recent Mammals of the World" (S. Anderson and J. K. Jones, Eds.), pp. 289-379. Wiley, New York.

Catzeflis, F. M., Sheldon, F. H., Ahlquist, J. E., and Sibley, C. G. (1987). DNA-DNA hybridization evidence of the rapid rate of muroid rodent DNA evolution. Mol. Biol. Evol. 4: 242-253.

Catzeflis, F. (1991). Animal tissue collections for molecular genetics and systematics. Trends Ecol. Evol. 6: 168.

Catzeflis, F. M., Aguilar, J.-P., and Jaeger, J.-J. (1992). Muroid rodents: Phylogeny and evolution. Trends Ecol. Evol. 7: 122-126.

Catzeflis, F. M., Dickerman, A. W., Michaux, J., and Kirsch, J. A. W. (1993). DNA hybridization and rodent phylogeny. In "Mammal Phylogeny" (F. S. Szalay, M. J. Novacek, and M. C., McKenna, Eds.), pp. 159-172. Springer-Verlag, New York.

Chaline, J., and Graf, J.-D. (1988). Phylogeny of the Arvicolidae (Rodentia): Biochemical and paleontological evidence. J. Mamm. 69: 22-33. 
Chaline, J., Mein, P., and Petter, F. (1977). Les grandes lignes d'une classification évolutive des Muroidea. Mammalia 41: 245-252.

Chevret, P., Denys, C., Jaeger, J.-J., Michaux, J., and Catzeflis, F. M. (1993a). Molecular evidence that the spiny mouse (Acomys) is more closely related to gerbils (Gerbillinae) than to true mice (Murinae). Proc. Natl. Acad. Sci. USA 90: 3433-3436.

Chevret, P., Denys, C., Jaeger, J.-J., Michaux, J., and Catzeflis, F. (1993b). Molecular and fossil aspects of the tempo and mode of evolution in Otomys (Otomyinae: Muridae: Mammalia). Biochem. Syst. Ecol. 21: 123-131.

Chevret, P., Granjon, L., Duplantier, J.-M., Denys, C., and Catzeflis, F. M. (1994). Molecular phylogeny of the Praomys complex (Rodentia, Murinae): A study based on DNA/DNA hybridization experiments. Zool. J. Linn. Soc. 112: 425-442.

de Bruyn, H., and Hussain, S. T. (1985). The succession of rodent faunas from the Lower Mancher Formation, southern Pakistan, and its relevance for the biostratigraphy of the Mediterranean Miocène. Paléobiol. Continentale (Montpellier) 14: 191-204.

de Graaff, G. (1981). "The Rodents of Southern Africa," Butterworths, Durban.

Denys, C., and Michaux, J. (1992). La troisième molaire supérieure chez les Muridae d' Afrique tropicale et le cas des genres Acomys, Uranomys et Lophuromys. Bonn. Zool. Beitr. 43: 367-382.

Denys, C., Michaux, J., Catzeflis, F., Ducrocq, S., and Chevret, P. (1995). Morphological and molecular data against the monophyly of Dendromurinae (Muridae: Rodentia). Bonn. Zool. Beitr. 45: 173190.

Dickerman, A. W. (1992). "Molecular Systematics of Some New World Muroid Rodents," PhD thesis, University of Wisconsin at Madison.

Dubois, J.-Y., Rakotondravony, D., Hänni, C., Sourrouille, P., and Catzeflis, F. M. (1996). Molecular evolutionary relationships of three genera of Nesomyinae, endemic rodent taxa from Madagascar. J. Mamm. Evol. 3: 239-260.

Dubois, J.-Y., Catzeflis, F. M., and Beintema, J. (1999). The phylogenetic position of "Acomyinae" (Rodentia, Mammalia) as sistergroup of a Murinae + Gerbillinae clade: evidence from the nuclear ribonuclease gene. Mol. Phylogenet. Evol. 13: 181-192.

Ellerman, J. R. (1940). “The Families and Genera of Living Rodents," Vol. 1, Br. Mus. (Nat. Hist.), London.

Ellerman, J. R. (1941). "The Families and Genera of Living Rodents," Vol. 2, Br. Mus. (Nat. Hist.), London.

Flynn, L. J. (1990). The natural history of rhizomyid rodents. In "Evolution of Subterranean Mammals at the Organismal and Molecular Levels" (E. Nevo, and O. A. Reig, Eds.), pp. 155-183. A. R. Liss, New York.

Flynn, L. J., Jacobs, L. L., and Lindsay, E. H. (1985). Problems in muroid phylogeny: Relationships to other rodents and origin of major groups. In "Evolutionary Relationships among Rodents" (W. P. Luckett, and J.-L. Hartenberger, Eds.), pp. 589-616. Plenum, New York.

Furano, A. V., Hayward, B. E., Chevret, P., Catzeflis, F., and Usdin, K. (1994). Amplification of the ancient murine Lx family of long interspersed repeated DNA occurred during the murine radiation. J. Mol. Evol. 38: 18-27.

Grasse, P. P. (1955). Traité de Zoologie (Anatomie, Systématique, Biologie), Tome XVII, Masson, Paris.

Hänni, C., Laudet, V., Barriel, V., and Catzeflis, F. M. (1995). Evolutionary relationships of Acomys and other murids (Rodentia, Mammalia) based on complete 12S rRNA mitochondrial gene sequences. Israel J. Zool. 41: 131-146.

Hartenberger, J.-L. (1985). The order Rodentia: Major questions on their evolutionary origin, relationships and suprafamilial systematics. In "Evolutionary Relationships among Rodents" (W. P.
Luckett and J.-L. Hartenberger, Eds.), pp. 1-33. Plenum, New York.

Hassanin, A., Pasquet, E., and Vigne, J.-D. (1998a). Molecular systematics of the subfamily Caprinae (Artyodactyla, Bovidae) as determined from cytochrome b sequences. J. Mamm. Evol. 5: 217236.

Hassanin, A., Lecointre, G., and Tillier, S. (1998b). The "volutionary signal" of homoplasy in protein coding gene sequences and its consequences for a priori weighting in phylogeny. C. R. Acad. Sci. Paris 321: 611-620.

Honacki, J. H., and Kinman, K. E. (1982). "Mammal Species of the World," Allen Press, New York.

Hooper, E. T., and Musser, M. D. (1964). The glans penis in Neotropical cricetines (Family Muridae) with comments on classification of muroid rodents. Misc. Publ. Univ. Michigan 123: 1-57.

Huchon, D., Catzeflis, F. M., and Douzery, E. J. P. (1999). Molecular evolution of the nuclear von Willebrand Factor gene in mammals and the phylogeny of rodents. Mol. Biol. Evol. 16: 577-589.

Hugueney, M., and Mein, P. (1993). A comment on the earliest Spalacinae (Rodentia, Muroidea). J. Mamm. Evol. 1: 215-223.

Jacobs, L. L., and Downs, W. R. (1994). The evolution of murine rodents in Asia. In "Rodent and Lagomorph Families of Asian Origin and Diversification" (Y. Tomida, C. Li, and T. Setoguchi, Eds.), Vol. 8, pp. 149-156, National Science Museum Monographs, Tokyo.

Jacobs, L. L., Flynn, L. J., and Downs, W. R. (1989). Neogene rodents of southern Asia. In "Papers on Fossil Rodents in Honor of Albert Elmer Wood" (C. C. Black, and M. R. Dawson, Eds.), Science Series No. 33, pp. 157-177. Nat. Hist. Mus. Los Angeles County, Los Angeles.

Jacobs, L. L., Flynn, L. J., Downs, W. R., and Barry, J. C. (1990). Quo vadis, Antemus? The Siwalik muroid record. In "European Neogene Mammal Chronology" (E. H. Linday, V. Fahlbusch, and P. Mein, Eds.), pp. 573-586. Plenum, New York.

Jaeger, J.-J., Tong, H., Buffetaut, E., and Ingavat, R. (1985). The first fossil rodents from the Miocene of northern Thailand and their bearing on the problem of the origin of the Muridae. Rev. Paléobiol. 4: 1-7.

Jaeger, J.-J., Tong, H., and Buffetaut, E. (1986). The age of MusRattus divergence: Paleontological data compared with the molecular clock. C. R. Acad. Sci. Paris Ser. 2 302: 917-922.

Jansa, S. A., Goodman, S. M., and Tucker, P. K. (1999). Molecular phylogeny and biogeography of the native rodents of Madagascar (Muridae: Nesomyinae): A test of the single-origin hypothesis. Cladistics 15: 253-270.

Kishino, H., and Hasegawa, M. (1989). Examination of the maximum likelihood estimate of the evolutionary tree topologies from DNA sequence data, and the branching order in Hominoidea. J. Mol. Evol. 29: 170-179.

Klingener, D. (1964). The comparative myology of four dipodoid rodents (genera Zapus, Napeozapus, Sicista and Jaculus). Misc. Publ. Mus. Zool. Univ. Michigan 124: 1-100.

Lavocat, R. (1973). Les rongeurs du Miocène d'Afrique Orientale. Mém. Trav. Ecole Pratique Hautes Etudes 1: 1-284.

Lavocat, R. (1978). Rodentia and Lagomorpha. In "Evolution of African Mammals" (V. J. Maglio, and H. B. S. Cooke, Eds.), pp. 69-89. Harvard Univ. Press, Cambridge, MA.

Lawrence, M. A. (1991). A fossil Myospalax cranium (Rodentia: Muridae) from Shanxi, China, with observations on Zokor relationships. Bull. Am. Mus. Nat. Hist. 206: 261-286.

Li, W. K., Tanimura, M., et al. (1987). An evaluation of the molecular clock hypothesis using mammalian DNA sequences. J. Mol. Evol. 25: $330-342$. 
McKenna, M. C., and Bell, S. K. (1997). "Classification of Mammals above the Species Level," Columbia Univ. Press, New York.

McLean, J. C., Fielding, D., Drayna, H., Dieplinger, B., Baer, W., Kohr, W., Henzel, W., and Lawn, R. (1986). Cloning and expression of human lecithin-cholesterol acyltranferase cDNA. Proc. Natl. Acad. Sci. USA 83: 2335-2339.

Martin, L. D. (1980). The early evolution of the Cricetidae in North America. Paleontol. Contrib. 102: 1-42.

Mein, P., and Ginsburg, L. (1997). Les mammiferes du gisement miocène inférieur de Li Mae Long, Thailande: Systématique, biostratigraphie et paléoenvironnement. Geodiversitas 19: 783-844.

Miller, G. S., and Gidley, J. W. (1918). Synopsis of the super-generic groups of rodents. J. Wash. Acad. Sci. 8: 431-448.

Misonne, X. (1971). Order Rodentia. In "The Mammals of Africa: An Identification Manual," (J. Meester, and H. W. Setzer, Eds.), Part 6, pp. 1-39. Smithsonian Institution Press, Washington, DC.

Musser, G. G., and Carleton, M. D. (1993). Family Muridae. In "Mammal Species of the World: A Taxonomic and Geographic Reference," (D. E. Wilson, and D. M. Reeder, Eds.), pp. 501-755. Smithsonian Institution Press, Washington, DC.

Nedbal, M. A., Honeycutt, R. L., and Schlitter, D. A. (1996). Higher level systematics of rodents (Mammalia, Rodentia): Evidence from the mitochondrial 12S gene. J. Mammal. Evol. 3: 201-237.

Ognev, S. I. (1963). Mammals of the USSR and adjacent countries: Rodents. Israel Program Sci. Translat. 5: 1-662.

O'hUigin, C., and Li, W. H. (1992). The molecular clock ticks regularly in muroid rodents and hamsters. J. Mol. Evol. 35: 377-384.

Pascale, E., Valle, E., and Furano, A. V. (1990). Amplification of an ancestral mammalian $\mathrm{L} 1$ family of long interspersed repeated DNA occurred just before the murine radiation. Proc. Natl. Acad. Sci. USA 87: 9481-9485.

Philippe, H. (1993). MUST, a computer package for management utilities for sequences and trees. Nucleic Acids Res. 21: 52645272.

Philippe, H. (1997). Rodent monophyly: Pitfalls of molecular phylogenies. J. Mol. Evol. 45: 712-715.

Reig, O. A. (1980). A new fossil genus of South American cricetid rodents allied to Wiedomys, with an assessment of the Sigmodontinae. J. Zool. 192: 257-281.

Robinson, M., Catzeflis, F., Briolay, J., and Mouchiroud, D. (1997). Molecular phylogeny of rodents, with special emphasis on murids: Evidence from nuclear gene LCAT. Mol. Phylogenet. Evol. 8: 423434.

Robinson, M., Gouy, M., Gautier, C., and Mouchiroud, D. (1998). Sensitivity of the relative-rate test to taxonomic sampling. $\mathrm{Mol}$. Biol. Evol. 15: 1091-1098.

Saitou, N., and Nei, M. (1987). The neighbor-joining method: A new method for reconstructing phylogenetic trees. Mol. Biol. Evol. 4: $406-425$.

Senegas, F., and Avery, D. M. (1998). New evidence for the murine origins of the Otomyinae (Mammalia, Rodentia) and the age of Bolt's Farm (South Africa). S. Afric. J. Sci. 94: 503-507.

Serdobova, I. M., and Kramerov, D. A. (1998). Short retroposon of the B2 superfamily: Evolution and application for the study of rodent phylogeny. J. Mol. Evol. 46: 202-214.
Simpson, G. G. (1945). The principles of classification and a classification of mammals. Bull. Am. Mus. Nat. Hist. 85: 1-350.

Smith, M. F., and Patton, J. L. (1999). Phylogenetic relationships and the radiation of sigmodontine rodents in South America: Evidence from cytochrome b. J. Mamm. Evol. 6: 89-129.

Strimmer, K. and von Haeseler, A. (1996). Quartet puzzling: A quartet maximum likelihood method for reconstructing tree topologies. Mol. Biol. Evol. 13: 964-969.

Swofford, D. L. (1998). PAUP*. Phylogenetic Analysis Using Parsimony (*and Other Methods). Version 4.0b. Sinauer, Sunderland, MA.

Tamura, K., and Nei, M. (1993). Estimation of the number of nucleotide substitutions in the control region of mitochondrial DNA in humans and chimpanzees. Mol. Biol. Evol. 10: 512-529.

Thomas, O. (1896). On the genera of rodents: An attempt to bring up to date the current arrangement of the order. Proc. Zool. Soc. London, pp. 1012-1028.

Thompson, J. D., Higgins, D. G., and Gibson, T. J. (1994). CLUSTAL $\mathrm{W}$ : Improving the sensitivity of progressive multiple sequence alignment through sequence weighting, positions-specific gap penalties and weight matrix choice. Nucleic Acids Res. 22: 4673-4680.

Tong, H. (1989). Origine et évolution des Gerbillidae (Mammalia, Rodentia) en Afrique du Nord. Mém. Soc. Géol. France 155: 1-120.

Tong, H., and Jaeger, J.-J. (1993). Muroid rodents from the Middle Miocene Fort Ternan locality (Kenya) and their contribution to the phylogeny of Muridae. Paleontographica Abt. A 229: 51-73.

Tullberg, T. (1899). Ueber das System der Nagetiere: Eine phylogenetische Studie. Nova Acta Reg. Soc. Sci. Upsala Ser. 3 18: 1-514.

Usdin, K., Chevret, P., Catzeflis, F. M., Verona, R., and Furano, A. V. (1995). L1 (LINE-1) retrotransposable elements provide a "fossil" record of the phylogenetic history of murid rodents. Mol. Biol. Evol. 12: 73-82.

Verheyen, E., Colyn, M., and Verheyen, W. (1996). A mitochondrial cytochrome $b$ phylogeny confirms the paraphyly of the Dendromurinae Alston, 1896 (Muridae, Rodentia). Mammalia 60: 780785.

Viegas-Pequignot, E., Petit, D., Benazzou, T., Prod'homme, M., Lombard, M., Hoffschir, F., Descailleaux, J., and Dutrillaux, B. (1986). Phylogénie chromosomique chez les Sciuridae, Gerbillidae et Muridae, et étude d'espèces appartenant à d'autres familles de Rongeurs. Mammalia 50: 164-202.

Warden, C. H., Langner, C. A., Gordon, J. I., Taylor, B. A., McLean, J. W., and Lusis, A. J. (1989). Tissue-specific expression, developmental regulation, and chromosomal mapping of the lecithin: Cholesterol acyltransferase gene. Evidence for expression in brain and testes as well as liver. J. Biol. Chem. 264: 21573-21581.

Wilson, D. E., and Reeder, D. M., Eds. (1993). "Mammal Species of the World: A Taxonomic and Geographic Reference," 2nd ed., Smithsonian Institution Press, Washington, DC.

Wu, C.-I., and Li, W. H. (1985). Evidence for higher rates of nucleotide substitutions in rodents than in man. Proc. Natl. Acad. Sci. USA 82: 1741-1745.

Zheng, S. (1994). Classification and evolution of the Siphneidae. In "Rodent and Lagomorph Families of Asian Origin and Diversification" (Y. Tomida, C. Li, and T. Setoguchi, Eds.), Vol. 8, pp. 57-76, National Science Museum Monographs, Tokyo. 